\title{
Modelling the Impact of Environmental and Organizational Determinants on Green Supply
}

\author{
Chain Innovation and Performance
}

\author{
Azadeh Rajabian Tabesh ${ }^{1}$, Peter J. Batt \& Bella Butler \\ School of Marketing, Curtin Business School, Curtin University, Perth, Australia
}

\begin{abstract}
Both customers and suppliers are becoming increasingly concerned about environmental issues in modern food chains. A firm's decision to implement green supply chain management is based on the social objectives of the firm and its management, its desire to pursue corporate social responsibility, its relationships with channel partners, and environmental determinants such as government legislation. The speed at which green supply chain management is implemented within an organization depends on its agility and its ability to facilitate innovation. Innovation may take the form of new product development or new process development, including the introduction of environmental management systems and total quality management in both production and purchasing. This article presents a conceptual model to explain how the various theoretical constructs are related and how innovation effects green supply chain management and performance.
\end{abstract}

KEYWORDS green supply chain, innovation, agility, corporate social responsibility

\section{INTRODUCTION}

Currently, there is an increasing worldwide demand for more sustainable food production, more environmentally friendly products, and waste reduction practices to improve efficiency and productivity (Burlingame \& Dernini, 2011). Although much attention has been directed toward environmental issues by company managers in Australia, there has been little practical change in this area (Schaper, 2002; Zhu \& Cote, 2004). The main reason for the reluctance is that many managers believe costs will increase if they apply green supply chain principles. However, the application of green supply chain management (GSCM) principles can improve product image and goodwill in the form of customers and society, and thereby improve market share (Eltayeb et al., 2011).

While previous studies have addressed environmental and organizational determinants in green supply chains, this article will focus on the relationship between organizational determinants (agility, corporate social responsibility, and the relational elements) and the environmental determinants (buyers, suppliers, and government) in green supply chains. The main purpose of this article is to present a conceptual framework to examine how environmental determinants impact organizational determinants in GSCM to improve performance.

\footnotetext{
${ }^{1}$ Azadeh Rajabian Tabesh, School of Marketing, Curtin University, Australia. AZADEH.RAJABIANTABESH@POSTGRAD.CURTIN.EDU.AU
} 


\section{GREEN SUPPLY CHAIN MANAGEMENT}

Supply chain management integrates suppliers, manufacturers, and distributors to meet consumer demands in an efficient and effective manner (Cooper, Lambert, \& Pagh, 1997, p. 2). Under this definition, supply chain management encapsulates all those activities from raw material supply to final product delivery (Beamon, 1999).

GSCM is defined by Beamon (1999) as an "extension of traditional supply chains to include activities that aim to minimize the environmental impacts of a product throughout its entire life cycle, such as green design, resource saving, harmful material reduction and product recycle or reuse" (pp. 339-340). Hence, the main purpose of GSCM is to reduce undesirable environmental impacts such as air, water, and land pollution and to reduce the waste of resources such as energy, materials, and products in the distribution process (Rao \& Holt, 2005; Eltayeb et al., 2011).

GSCM contributes to increased sustainability within food supply chains by increasing the efficiency of production, processing and distribution, protecting the quality and safety of food, promoting fair and transparent distribution, and increasing consumer access to healthy food at affordable prices (Lazarides, 2011). The main benefits of GSCM are environmental (reduced emission of greenhouse gases), technological (a platform for technological advancement by finding areas of high impact to decrease environmental degradation), economic (reduced disposal costs from decreased waste), and social (a safer workplace and clean working environment; Emmett \& Sood, 2010).

The implementation of green supply chain practices can provide valuable opportunities to improve firm performance (Zhu \& Sarkis, 2004). Azevedo et al. (2011), Linton et al. (2007), Green et al. (2012), and Rao and Holt (2005) demonstrated the importance of integrating environmental management practices into the supply chain to achieve better economic performance and enhance competitive advantage. Florida and Davison (2001), Geffen and Rothenberg (2000), Handfield et al. (2002), Green et al. (2012), Hervani et al. (2005), Zhu, Sarkis, and Geng (2005), Azevedo et al. (2011), Large and Thomsen (2011), Chiou et al. (2006), and Chen et al. (2011) also discussed the relationship between GSCM practices and firm performance.

In what is a saturated market, if firms are to differentiate themselves from their competitors, they must develop innovative ways to address the environmental concerns of customers and to decrease the negative impact of their activities on the environment (Rao \& Holt, 2005). Innovations such as decreasing pollution, reducing dangerous waste, and responding quickly to customers' demands can position the firm more favorably in the market (Chiou et al., 2011). On the other hand, environmental pressures for GSCM can force companies to be innovative. Although environmental determinants can be categorized in various ways, the primary variables include government legislation (Hippel, 2009; Eyestone, 1977), suppliers (Rao, 2002; Shrivastava, 1995), and buyers (Schiele, 2006).

\section{PERFORMANCE}

Performance is measured using a number of multiple outcomes including economic, environmental, and operational. Environmental outcomes may include a reduction in the amount of waste (Bowen et al., 2001; Rao, 2002; Zhu \& Sarkis, 2004; Zhu et al., 2007); economic outcomes include greater profitability, increased sales and market share (Rao \& 
Holt, 2005; Zhu \& Sarkis, 2004), and reduced costs (Aramyan, 2007); wheras operational outcomes include cost reductions and improved quality (Rao \& Holt, 2005; Vachon \& Klassen, 2006), reduced inventory levels, reduced throughput time, greater responsiveness, and more reliable delivery (Aramyan, 2007). Within the supply chain, performance indicators include product availability, quality, responsiveness, reliability of delivery, and total supply chain costs (Aramyan, 2007). However, striving to maximize one or more of these indicators is expected to lead to some conflict as maximizing one (environmental performance) may be detrimental to another (economic performance).

There is a significant body of research to show that innovation has a positive impact on organizational performance (Hao, Kasper, \& Muehlbacher, 2012; Huang, Lai, \& Lo, 2012; Ruiz-Jiménez \& Fuentes-Fuentes, 2012). Implementing principles of GSCM requires many changes to be made to a company's supply chain, such as designing new products and processes; employing new capabilities; executing alternative purchasing functions; and selecting new suppliers, customers, and third-party logistics providers (Yen \& Yen, 2012; Mutingi \& Mbohwa, 2012). GSCM practices can improve environmental performance through reducing gas emission, energy consumption, and hazardous wastes and ensuring compliance with environmental standards (Rao, 2002; Zhu et al., 2008). Financial performance is improved as result of waste reduction and cost savings (Curkovic et al., 2000; Wu \& Pagell, 2011).

Legislation plays an important role in forcing companies to implement green practices via penalties or sanctions. For example, the Australian Clean Energy Regulator is a government body responsible for administering legislation to reduce carbon emissions and increase the use of clean energy. In the farming sector, this organization helps individual businesses to reduce their greenhouse gas emissions (Australian Government-Carbon Farming Initiative, 2013). Similar organizations operate in the United Kingdom under the Climate Change Act (2008) and in the United States under the Clean Energy Bill (2009). In recent years the environmental protection legislation was also introduced in emergent countries. For example, in China, companies have to employ green production principles by law (Lai \& Wong, 2012).

Equally important is the desire of some of the world's largest manufacturers and retailers to pursue GSCM. For example, Walmart, a giant international retailer, acting implementing its Sustainable Packaging Program, expressed the commitment toward sustainability and environmental protection in 2005. This will allow decreasing the costs of packaging and will neutralize its negative impact on the environment. In car manufacturing, Toyota has recently developed a hybrid technology that led to the production of environmentally friendly vehicles that use less fuel and enable a decrease in greenhouse gas emissions (Toyota Motor Europe Corporate Site, 2010).

\section{A CONCEPTUAL MODEL OF GREEN SUPPLY INNOVATION}

\section{GSCM Innovation}

Cohen and Levinthal (1990), Teece and Pisano (1994), and Hervani et al. (2005) have described how companies vary in their organizational resources and procedures, which consequently affects their ability to respond to organizational and environmental challenges. 
Organizational capabilities include factors such as organizational resources, organizational innovativeness, and organizational monitoring systems. Constraints may include the lack of financial resources, organizational structure, organizational resistance to change, a lack of training (del Brio \& Junquera, 2003), and the inability to access technologies and markets (Hervani et al., 2005).

Knowledge processes increase environmental innovations (Smirnova et al., 2011). The availability of substantial bodies of organizational expertise within firms is an important resource for improving environmental product and process innovations (Smirnova et al., 2011).

Innovation includes new product development (NPD) and new process development (Klassen \& Whybark, 1999; Porter \& Van der Linde, 1995; Chen et al., 2006; Chen, 2008), which, in the context of GSCM, includes the implementation of environmental management systems (EMS; Wagner, 2007), total quality management (TQM; Prajogo \& Sohal, 2003; Chandra, 1993), and purchasing (Murray, 2000; Schiele, 2006). Significant capabilities to facilitate the process of innovation include management's obligation to improve the firm's environmental impact and regularly scrutinize the firm's use of natural resources (Darnall et al., 2008), agility (Goldman et al., 1995), and the methods that the firm employs to manage its relationships with channel partners.

\section{New Product Development}

New product development (NPD) can be defined along two dimensions: newness to the firm and newness to markets (Booz, Allen, \& Hamilton, 1982, cited in Ilori et al., 2000). It also covers a wide range of dimensions from low to high, including new product development, additions to existing product lines, new product lines, and new markets.

Innovation is an essential part of corporate strategy if firms are to offer products that meet consumers' changing demands. Changing lifestyles lead to the need for greater convenience (Trienekens et al., 2008; Karantininis et al., 2010), improved product safety and food quality (Batt \& Noonan, 2009; Lazarides, 2011; Pereira \& Vicente, 2010), packaging, and technology (Mahalik \& Nambiara, 2010).

\section{Environment Management Systems}

An environmental management system (EMS) is described as a strategic management approach that shows how firms address their impact on the environment. Organizations employ EMS because they can increase environmental performance and profitability (Bansal \& Hunter, 2003; Darnall et al., 2008). Implementing EMS standards such as ISO 14001 can enhance environmental innovation by encouraging firms to establish environmental goals that lead to improved environmental performance (Clapp, 1998; Zhu et al., 2012).

An EMS is a collection of organizational policies, assessments, plans, and actions for implementation (Coglianese \& Nash, 2001; Krut \& Gleckman, 1998) that may have a significant impact on the firm and its relationships with its environment. There is a complementary relationship among EMS and GSCM because both seek to provide a more comprehensive means of establishing sustainability among business networks (Darnall et al., 2008).Both EMS and GSCM rely on constant improvement to decrease the firm'simpact on the environment. 


\section{Green Purchasing}

There is a significant link between green purchasing, innovation, and performance (Håkansson \& Erikssona, 1993; Schiele, 2006). Selecting appropriate suppliers who are able to support and contribute to innovation is a key task for purchasing. However, while green purchasing can improve the speed at which a firm is able to respond to changing customer needs (Meier et al., 1998), it can result in increased material costs, and the firm may experience greater difficulty in identifying a qualified supplier base (Min \& Galle, 1997).

Green purchasing is defined as the combination of purchasing actions to an environmental issue, which may lead to improved performance (Large \& Thomsen, 2011, p. 177). Green purchasing can decrease the amount of waste material that is harmful to the environment, through purchasing recyclable and returnable packaging material. However, the high cost of environmental programs, the inability to recycle and reuse, the lack of management commitment, a lack of buyer and supplier awareness, and the absence of environmental standards limit the effectiveness of green purchasing (Rao \& Holt, 2005; Min \& Gale, 1997).

\section{Total Quality Management}

Total quality management (TQM) is an integrated management attitude and set of practices that emphasizes emphasize "continuous improvement, meeting customers' requirements, long-range thinking, greater employee participation, motivating process redesign, competitive benchmarking, problem solving groups and closer relationships with customers and suppliers" (Ross, 1993, p. 1-2). TQM covers many aspects of the firm's activities, including quality, customers, employees, production, and management to initiate significant changes (Hackman \& Wageman, 1995), to innovate to meet customer requirements (Ehigie \& McAndrew, 2005), and to reduce costs (Henson \& Reardon, 2005). Cross-functional management, which is facilitated by TQM, is necessary to execute GSCM.

However, TQM can also stifle innovation. The main reason for this outcome is that managing innovation is different from managing quality (Prajogo \& Sohal, 2003). Firms should choose between quality and innovation to enhance performance (Flynn, 1994; McAdam et al., 1998). Conversely, TQM can be seen as an innovation (Cooper, 1998; Westphal et al., 1997; Yamin et al., 1997), because the successful implementation of TQM will have a number of significant and positive effects on performance in the long term (Prajogo \& Sohal, 2003). In this regard, access to up-to-date information plays an important role in achieving successful TQM (Hervani et al., 2005). Each of these arguments led to the following propositions: 


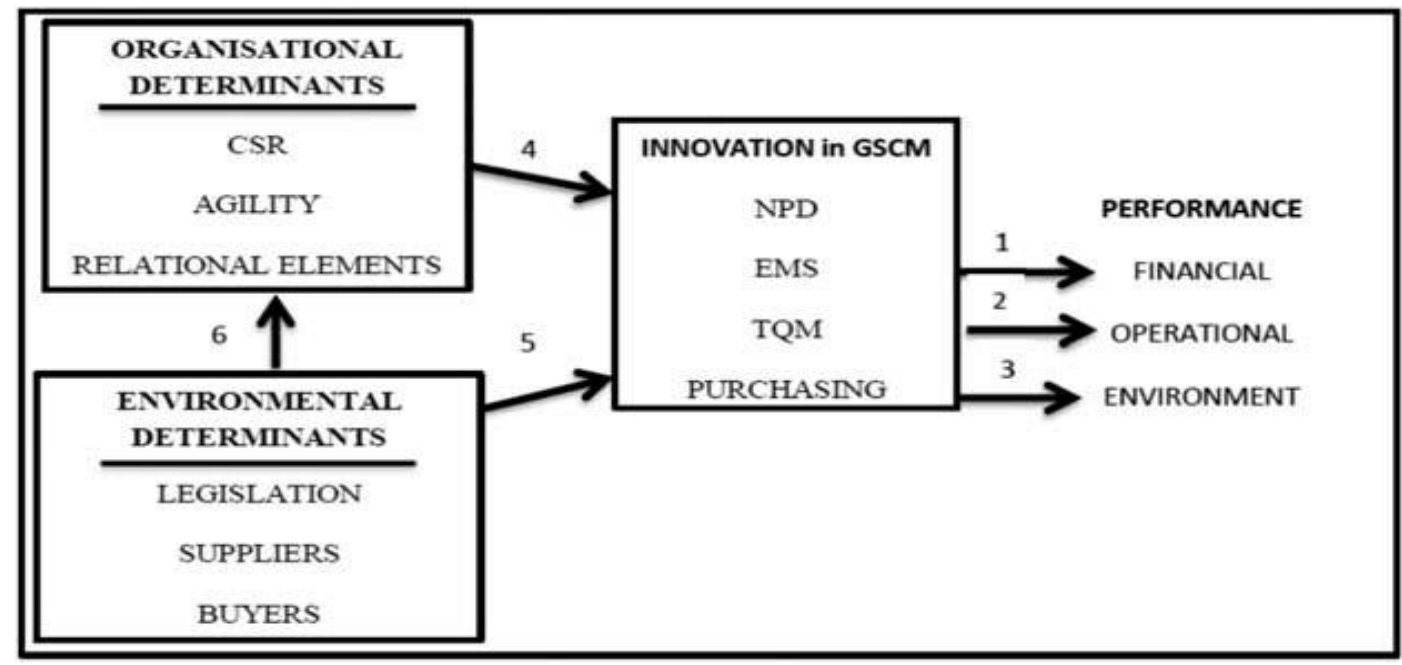

FIGURE 1 Research framework.

Each of these arguments led to the following propositions:

Proposition 1: Innovation in GSCM will have a positive direct impact on financial performance

Proposition 2: Innovation in GSCM will have a positive direct impact on operational performance

Proposition 3: Innovation in GSCM will have a positive direct impact on environmental performance (Figure 1).

\section{ORGANIZATIONAL DETERMINANTS}

\section{Agility}

Goldman et al. (1995) defined an agile company as active, context-specific, changeembracing, and growth-oriented (pp. 59-60). It is dynamic because the manner in which an organization achieves agility today may not be effective tomorrow. It is context-specific because the market environment can affect the required level of agility.

Agility can facilitate innovation in GSCM. Agility is related to the organization's ability to reconceive its vision, renew its strategies, and redevelop its methods (Hamel \& Prahalad, 1994, cited in Swafford et al., 2006). A dynamic market with rapidly changing customer demands requires an agile supply chain to shorten the time required to respond to the customers' needs (Goldman et al., 1994). Agile supply chains require business partners to collaborate to enable new competencies to develop in a timely manner in response to rapidly changing, continually fragmenting markets (Baramichai et al., 2007).

\section{Corporate Social Responsibility}

Corporate social responsibility (CSR) is a "decision making and implementation process that guides all firm activities in the protection and promotion of international human rights, labor and environmental standards and compliance with legal requirements within its 
operations and in its relationships with society and the communities within which it operates" (Emmett \& Sood, 2010, p. 11).

CSR has a strong connection with GSCM. The aim of sustainability is to decrease the consumption of nonrenewable resources, reduce waste, and sustain healthy environments (Emmett \& Sood, 2010). According to Murphy and Poist (2002), supply chain practitioners have been slow to adopt CSR (Batterman \& Amann, 1991).

CSR can increase shareholder value through innovation (Husted \& Allen, 2007). Social responsibility includes various activities such as the production of environmentally friendly products, strategies to reduce pollution, product safety, and innovation (Tang et al., 2012).

CSR assumes that firms believe they are responsible in some way to contribute to a society (Wood, 1991). Moreover, it is important to consider that firms do not always focus on increasing the firm's economic performance, but may also implement environmental clean-up programs, community development programs, and employee welfare programs (Bansal \& Hunter, 2003). Most firms consider CSR as being a way to improve their profitability (McWilliams \& Siegel, 2001; Weisenfeld, 2012).

\section{Relational Elements}

Relationships in the supply chain play a significant role in increasing innovation because of the connections between resources and actors, the complementary nature of the activity structures, and the bonds established between individual actors (Ford et al., 1998).

Greater collaboration among the members of a supply chain fosters the development of improved environmental management systems through innovation (Geffen \& Rothenberg, 2000). Collaboration between buyers and suppliers also reduces the cost of NPD, having a favorable impact on new product design, process design, and reducing new product development times to improve firm performance (Chen, 2008; Chiou et al., 2011; Terpend et al., 2008).

A key dimension of relational coordination is cooperation (Hakansson \& Snehota, 1995), which requires mutual effort and collaboration between exchange partners. Cooperation can be defined as "similar or complementary coordinated actions taken by firms in interdependent relationships to achieve mutual outcomes or singular outcomes with expected reciprocation over time" (Anderson \& Narus 1990, p. 45). The extent to which firms cooperate is influenced by (1) the degree to which the parties believe that they can simultaneously achieve their goals; (2) the existence of a mutual agreement between the parties concerning their actions in achieving individual goals; (3) the perceptual clarity of the information processed by the interacting parties; (4) the establishment of mutually accepted norms based on the achievement of individual goals; and (5) the acceptance of norms of exchange, which protect from opportunistic and self-centered behaviour (Leonidou, 2004).

Cooperation is influenced by commitment and trust (Ford et al., 1998). Commitment is an essential aspect of a long-term relationship (Hakansson \& Snehota, 1995). Commitment "captures the perceived continuity or growth in the relationship between two firms" (Anderson et al., 1994, p. 10). It includes "a desire to develop a stable relationship, a 
willingness to make short term sacrifices to maintain the relationship and confidence in the stability of the relationship" (Anderson \& Weitz, 1992, p. 19).

To achieve commitment, trust is a critical factor (Moorman et al., 1992; Morgan \& Hunt, 1994; Walter et al., 2000). Trust describes a belief that one relationship partner will act in the best interests of the other partner (Wilson, 1995). Trust creates value, which increases the desire to commit to the relationship (Hrebiniak, 1974). Trust will increase when (1) the other party has a reputation for being fair and is concerned about achieving mutual welfare; (2) past outcomes from the working relationship have been satisfactory; and (3) the two parties have successfully resolved critical problems in the relationship (Ganesan, 1994; Leonidou, 2004).

Trust promotes well-timed communication (Morgan \& Hunt, 1994). Communication can be defined as "the formal as well as informal sharing of meaningful and timely information between firms" (Anderson \& Narus, 1990, p. 44). Communication behavior includes communication quality, the extent of information sharing, and the level of participation and input into joint concerns (Mohr \& Spekman, 1994). Communication considers the extent to which the exchange of information is frequent, formal, bidirectional (to include positive and negative feedback), and non-coercive (Mohr et al., 1999).

The balance of power and the degree of dependence or interdependence in a relationship will influence the process of coordination through trust and commitment (Kothandaraman \& Wilson, 2000; Kumar et al., 1995). As power is rarely distributed equally in an interfirm relationship, power is directly related to the perceived degree that one exchange partner feels it is more or less dependent on its exchange partner (Wilson, 1995). That firm that holds the majority of the power will generally influence the behavior of others. Kaplinski and Morris (2001) described how activities, actors, roles, and functions are coordinated through power asymmetry. More powerful actors in the supply chain assume responsibility for the interfirm division of labor, monitoring outcomes, linking discrete activities between actors, establishing and managing relationships between the various actors, and organizing logistics. However, coordination does not require a single firm to engage in these roles: indeed, there may be a multitude of firms coordinating the flow of product and activities along the chain. Ogbonna and Wilkinson (1998) argued that the power to control is not only dependent on the possession of power but also the extent to which other exchange partners have countervailing market power. The presence of countervailing power forces exchange partners to differentiate between the possession of power and its use.

While the power to coordinate is the prerogative of the dominant firm (Achrol, 1997), it is the subsequent use of that power that will influence the exchange partner's perception of relationalism (Brown et al., 1995). Numerous reward and coercive powers and legitimate authority have been used by channel leaders to cajole cooperation between channel members. However, the frequent use of mediated power is likely to damage relational norms, cooperation, and accommodation between channel partners (Brown et al., 1995). Overt attempts to directly influence weaker parties through the use of mediated power are generally viewed with considerable disfavor. Not only will this lead to conflict, but the relative attractiveness of alternative exchange partners will increase. Conversely, the use of nonmediated power inevitably builds social bonds and close relationships. It is widely accepted that expert power, once expended, is lost (Achrol, 1997; Batt, 2004). Expertise is therefore something that has to be continually redeveloped, promoted, and communicated. These arguments lead to the proposition that 
Proposition 4: Organizational determinants will have a positive direct impact on innovation.

\section{ENVIRONMENTAL DETERMINANTS}

Companies face many external pressures that affect the performance of their supply chains. The three main variables are the bargaining powers of customers, the bargaining power of suppliers (Porter, 1980), and government legislation. This session discusses the impact of these three forces on the environmental actions of companies.

\section{Legislation and Policy}

To acknowledge the potential destructive effects of human activities on nature, attention toward environmental awareness has increased among public and nongovernment organizations (NGO) (Welford, 2000; Vandergeest, 2007; Andonova \& Mitchell, 2010). For example, in Australia a special institution, namely the Australian Government Clean Energy Regulator, was established. This organization requires companies to implement environmental protection measures (Australian Government-Clean Energy Regulator, 2013). It also controls the implementation of the Carbon Farming Initiative (CFI), which is aimed at reduction of greenhouse gas emissions by companies. For example, in the dairy industry this initiative is implemented, in the feeding of milking cows. Various additives such as canola meal, coldpressed canola meal, brewer's grain, hominy meal, or dried distiller's grain, when added to the feed, reduce the amount of methane $(\mathrm{CH} 4)$ produced as a result of enteric fermentation (digestive process in ruminant animals; Australian Government-Clean Energy Regulator, 2013).

Environmental regulations are a strong and powerful determinant of innovation in green supply chains (Carter \& Dresner, 2001; Preuss, 2005; Lee, 2008; Walker et al., 2008). However, concerns about increasing costs are the main reason for failures in the green market (Ginsberg \& Bloom, 2004). Conversely, GSCM can deliver more benefits for companies than the increased costs associated with their implementation. These benefits include enhanced brand image and improved relationships with stakeholders (Testa \& Iraldo, 2010; Xie \& Breen, 2012).

In neoclassical economics, regulation can reduce productivity and competitiveness because it increases costs (Ambec et al., 2011). However, legislation and the need for firms to comply or risk market exclusion, fines, or sanctions also provide a powerful incentive for the introduction of green practices. Therefore, environmental regulation and producers need to comply, which leads to innovation and more efficient resource use (Ambec et al., 2011). How quickly firms can adapt to environmental pressures will differ from firm to firm depending on their capabilities.

\section{Suppliers}

According to Vachon and Klassen (2006) and Walker et al. (2008), cooperation between suppliers can increase a firm's capability to implement environmental issues more effectively. Green suppliers can increase innovation in green supply chains (Rao, 2002; Shrivastava, 1995), leading to improved environmental performance. In green supply chains, collaborative activities may include cross-functional communication and the sharing of financial, human, and technical resources (Lee, 2008); supplier education such as informing 
the suppliers about the benefits of green practices (Hu \& Hsu, 2010; Rao, 2002); visiting suppliers sites to provide technical assistance (Walton et al., 1998); and joint ventures to collectively develop green innovations (Eltayeb et al., 2011; Hu \& Hsu, 2010; Vachon \& Klassen, 2006).

For instance, Monsanto, an American agro chemical company, collaborates with its partners, such as Agraquest, Mendel Biotechnology, and Dow AgroScience, to improve their products and processes. In one of the recent projects, Monsanto has worked in partnership with KUBO Sustainable Greenhouse Projects, a leader in the construction of sustainable greenhouses from Holland, and Houweling's Tomatoes, a North American tomato grower, to implement a Guatemala Greenhouse Project with the aim of providing "a source of nutrition for local school children and knowledge about farming best-practices to local farmers" (Monsanto Newsroom, 2013, p. 1). This partnership was necessary to address a problem of lost seeds in Guatemala. Seeds often are washed away by rainstorms so that they would not take root. The greenhouse technology project that is currently being implemented by Monsanto and its partners helps in saving the seeds from being washed away (Monsanto Newsroom, 2013).

\section{Buyers}

Powerful customers and their environmental concerns challenge companies to introduce GSCM principles. Relationships with powerful buyers are a strong incentive for companies to implement green practices (Wang et al., 2012; Vachon \& Klassen 2009). For example, buyers may force their suppliers to use recyclable packaging (Laosirihongthong, Adebanjo, \& Tan, 2013). In Australia, Woolworths, one of the leading retailers, requires its suppliers to decrease the negative impact of their activities on the ocean. Specifically, under this initiative funds are allocated for professional fishermen to reduce the amount of damage to ocean habitats and to reduce the catch of non-target species (Woolworths' Sustainability Strategy, 2007-2015). Other requests of Woolworths to its suppliers include decrease of carbon emissions, the use of recycled packaging, more efficient water usage, and waste reduction.

Buyers are often the key driver of GSCM as changes in their procurement practices can encourage suppliers to become more innovative to improve environmental performance (Lee, 2008). However, such efforts can increase the cost (Min \& Galle, 1997).

These arguments lead to two further propositions:

Proposition 5: Environmental determinants will have a direct positive impact on innovation.

Proposition 6: Environmental determinants will have an indirect positive impact on innovation through the organizational determinants.

\section{CONCLUSIONS}

This article has developed a conceptual model to investigate how organizational and environmental determinants influence innovation in green supply chains leading to improved organizational performance. To empirically test the model, data will be collected from selected food companies in the western Australian food industry: fresh produce, dairy, and 
seafood. Face-to-face interviews, guided by a semistructured questionnaire, will be administered to marketing managers, research and development (R\&D) managers, purchasing managers, chief executive officers (CEO), and chief financial officers (CFO) within the selected food companies and their various upstream suppliers and downstream customers. To evaluate how the individual firms in the focal supply chains facilitate innovation in response to changes in the organizational and environmental determinants, it will be necessary to move backward and forward between interviews and the analyses of the data (Dubois \& Gadde, 2002).

\section{REFERENCES}

Andonova, L. B., \& Mitchell, R. B. (2010). The rescaling of global environmental politics. Annual Review of Environment and Resources, 35, 255-282.

Achrol, R. S. (1997). Changes in the theory of interoganisational relations in marketing: Toward a network paradigm. Journal of the Academy of Marketing Science, 25, $56-71$.

Ambec, S., Cohen, M. A., Elgie, S., \& Lanoie, P. (2011). The Porter hypothesis at 20: Can environmental regulation enhance innovation and competitiveness? (Discussion Paper). Washington, DC: Resources for the Future. Retrieved from http://www.rff.org/documents/RFF-DP-11-01.pdf

Anderson, J. C., Hakansson, H., \& Johanson, J. (1994). Dyadic business relationships within a business network context. Journal of Marketing, 58(4), 1-15.

Anderson, J. C., \& Narus, J. A. (1990). A model of distributor firm and manufacturing firm working relationships. Journal of Marketing, 54, 42-58.

Anderson, E., \& Weitz, B. A. (1992). The use of pledges to build and sustain commitment in distribution channels. Journal of Marketing Research, 29, 18-34.

Aramyan, L. H. (2007). Measuring supply chain performance in the agri-food sector (Doctoral thesis). Wageningen University, Wageningen, the Netherlands.

Azevedo, S. G., Carvalho, H., \& Machado, V. C. (2011). The influence of green practices on supply chain performance: A case study approach. Transportation Research Part E: Logistics and Transportation Review, 47, 850-871.

Bansal, P., \& Hunter, T. (2003). Strategic explanations for the early adoption of Iso 14001. Journal of Business Ethics, 46, 289-299.

Baramichai, M., Zimmers, E. W., \& Marangos, C. S. A. (2007). Agile supply chain transformation matrix: An integrated tool for creating an agile enterprise. Supply Chain Management, 12, 334-348. 
Batt, P. J. (2004). Power-dependence in agricultural supply chains: Fact or fallacy? In Proceedings of 20th Annual Conference of the Industrial Marketing and Purchasing Group (pp. 1-15). Copenhagen, Denmark.

Batt, P. J., \& Noonan, J. (2009). Global trends in food quality: An exploratory study in fresh produce supply chains. Acta Horticulturae, 831, 95-104.

Batterman, S. A., \& Amann, M. (1991). Targeted acid rain strategies including uncertainty. Journal of Environmental Management, 32, 57-72.

Beamon, B. M. (1999). Designing the green supply chain. Logistics Information Management, 12, 332-342.

Bowen, F. E., Cousins, P. D., Lamming, R. C., \& Farukt, A. C. (2001). The role of supply management capabilities in green supply. Production and Operations Management, 10, 174-189.

Brown, J. R., Lusch, R. F., \& Nicholson, C. Y. (1995). Power and relationship commitment: Their impact on marketing channel member performance. Journal of Retailing, $71,363-392$.

Burlingame, B., \& Dernini, S. (2011). Sustainable diets: The Mediterranean diet as an example. Public Health Nutrition, 14(Special Issue 12A), 2285-2287.

Carbon Farming Initiative. (2013). Australian government-Clean energy regulator. Retrieved from http://www.cleanenergyregulator.gov.au

Carter, C. R., \& Dresner, M. (2001). Purchasing's role in environmental management: Cross-functional development of grounded theory. Journal of Supply Chain Management, 37(3), 12-26.

Chandra, M. (1993). Total quality management in management development. Journal of Management Development, 12(7), 19-31.

Chen, Y. S., Lai, S. B., \& Wen, C. T. (2006). The influence of green innovation performance on corporate advantage in Taiwan. Journal of Business Ethics, 67, 331-339.

Chen, Y. (2008). The driver of green innovation and green image-Green core competence. Journal of Business Ethics, 81, 531-543.

Chiou, T. Y., Chan, H. K., Lettice, F., \& Chung, S. (2011). The influence of greening the suppliers and green innovation on environmental performance and competitive advantage in Taiwan. Transportation Research Part E: Logistics and Transportation Review, 47, 822836.

Clapp, J. (1998). The privatization of global environmental governance: ISO 14000 and the developing world. Global Governance, 4, 295-316.

Coglianese, C., \& Nash, J. (2001). Regulating from the inside: Can environmental management systems achieve policy goals? Washington, DC: Resources for the Future. 
Cohen, W. M., \& Levinthal, D. A. (1990). Absorptive capacity: A new perspective on learning and innovation. Administrative Science Quarterly, 35, 128-152.

Cooper, J. R. (1998). A multidimensional approach to the adoption of innovation. Management Decision, 38, 493-502.

Cooper, M. C., Lambert, D. M., \& Pagh, D. (1997). Supply chain management: More than a new name for logistics. International Journal of Logistics Management, 8, 1-14.

Curkovic, S., Melnyk, S. A., Handfield, R. B., \& Calantone, R. J. (2000). Investigating the linkage between total quality management and environmentally responsible manufacturing. IEEE Transactions on Engineering Management, 47, 444-446.

Darnall, N., \& Edwards, D. (2006). Predicting the cost of environmental management system adoption: The role of capabilities, resources and ownership structure. Strategic Management Journal, 27, 301-320.

Darnall, N., Jolley, G. J., \& Handfield, R. (2008). Environmental management systems and green supply chain management: Complements for sustainability? Business Strategy and the Environment, 17, 30-45.

Del Brío, J. Á., \& Junquera, B. (2003). A review of the literature on environmental innovation management in SMES: Implications for public policies. Technovation, 23, 939948.

Dubois, A., \& Gadde, L. E. (2002). Systematic combining: An abductive approach to case research. Journal of Business Research, 55, 553-560.

Ehigie, B. O., \& McAndrew, E. B. (2005). Innovation, diffusion and adoption of total quality management (TQM). Management Decision, 43, 925-940.

Eltayeb, T. K., Zailani, S., \& Ramayah, T. (2011). Green supply chain initiatives among certified companies in Malaysia and environmental sustainability: Investigating the outcomes. Resources, Conservation and Recycling, 55, 495-506.

Emmett, S., \& Sood, V. (2010). Green supply chains: An action manifesto. New York, NY: John Wiley \& Sons.

Eyestone, R. (1977). Confusion, diffusion, and innovation. American Political Science Review, 71, 441-447.

Florida, R., \& Davison, D. (2001). Gaining from green management: Environmental management systems inside and outside the factory. California Management Review, 43, 6484.

Flynn, B. B., Schroeder, R. G., \& Sakakibara, S. (1994). A framework for quality management research and an associated measurement instrument. Journal of Operations Management, 11, 339-366. 
Ford, D., Gadde, E., Hakansson, H., Lundgren, A., Snehota, I., Turnbull, P., \& Wilson, D. (1998). Managing business relationships. Chichester, UK: Wiley.

Ganesan, S. (1994). Determinants of long-term orientation in buyer-seller relationships. Journal of Marketing, 58, 1-19.

Geffen, C., \& Rothenberg, S. (2000). Sustainable development across firm boundaries: The critical role of suppliers in environmental innovation. International Journal of Operations \& Production Management, 20, 166-186.

Ginsberg, J. M., \& Bloom, P. N. (2004, October). Choosing the right green marketing strategy. MIT Sloan Management Review. Retrieved from http://sloanreview.mit. edu/article/choosing-the-right-greenmarketing-strategy/

Goldman, S. L., Nagel, R. N., \& Preiss, K. (1995). Agile competitors and virtual organizations: Strategies for enriching the customer. New York, NY: Van Nostrand Reinhold.

Goodwin, B. K., \& Brester, G. W. (1995). Structural change in factor demand relationships in the U.S. food and kindred products industry. American Agricultural Economics Association, 77, 69-79.

Green, K. W., Zelbst, P. J., Meacham, J., \& Bhadauria, V. S. (2012). Green supply chain management practices: Impact on performance. Supply Chain Management, 17, 290305 .

Hackman, J. R., \& Wageman, R. (1995). Total quality management: Empirical, conceptual, and practical issues. Administrative Science Quarterly, 40, 309-342.

Handfield, R., Walton, S. V, Sroufe, R., \& Melnyk, S. A. (2002). Applying environmental criteria to supplier assessment: A study in the application of the analytical hierarchy process. European Journal of Operational Research, 141, 70-87.

Hakansson, H., \& Erikssona, A. K. (1993). Getting innovations out of the supplier networks. Business-to-Business Marketing, 1(3), 3-34.

Hakansson, H., \& Snehota, I. (1995). Developing relationships in business networks. London, UK: International Thomson Business Press.

Hao, Q., Kasper, H., \& Muehlbacher, J. (2012). How does organizational structure influence performance through learning and innovation in Austria and China. Chinese Management Studies, 6, 36-52.

Henson, S., \& Reardon, T. (2005). Private agri-food standards: Implications for food policy and the agri-food system. Food Policy, 30, 241-253.

Hervani, A., Helms, M. M., \& Sarkis, J. (2005). Performance measurement for green supply chain management. Benchmarking: An International Journal of Business Research, $12,330-353$. 
Hippel, E. V. (2009). Democratizing innovation: The evolving phenomenon of user innovation. International Journal of Innovation Science, 1, 29-40.

Hrebiniak, L. G. (1974). Effects of job level and participation on employee attitude and perceptions of influence. Academy of Management Journal, 17, 649-662.

Hu, A. H., \& Hsu, C. W. (2010). Critical factors for implementing green supply chain management practice: An empirical study of electrical and electronics industries in Taiwan. Management Research Review, 33, 586-608.

Huang, H. C., Lai, M. C., \& Lo, K. W. (2012). Do founders' own resources matter? The influence of business networks on start-up innovation and performance. Technovation, $32,316-327$.

Husted, B. W., \& Allen, D. B. (2007). Strategic corporate social responsibility and value creation among large firms: Lessons from the Spanish experience. Long Range Planning, 40, 594-610.

Ilori, M. O., Oke, J. S., \& Sanni, S. A. (2000). Management of new product development in selected food companies in Nigeria. Technovation, 20, 333-342.

Ruiz-Jiménez, J. M., \& Fuentes-Fuentes, M. M. (2013). Knowledge combination, innovation,

organizational performance in technology firms. Industrial Management \& Data Systems, 113, 523-540.

Kaplinsky, R., \& Morris, M. (2000). A handbook for value chain research. IDS, University of Sussex. Retreived from http://www.prism.uct.ac.za/Papers/VchNov01.pdf

Karantininis, K., Sauer, J., \& Furtan, W. H. (2010). Innovation and integration in the agri-food industry. Food Policy, 35, 112-120.

Klassen, R. D., \& Whybark, D. C. (1999). The impact of environmental technologies on manufacturing performance. Academy of Management Journal, 42, 599-615.

Kothandaraman, P., \& Wilson, K. (2000). Implementing relationship strategy, ISBM Report 1-2000, Institute for the Study of Business Markets, Pennsylvania.

Krut, R., \& Gleckman, H. (1998). ISO 14001: A missed opportunity for sustainable global industrial development. London, UK: Earthscan. Research in Corporate Social Performance and Policy Supplement 1, 99-126.

Kumar, N., Scheer, L. K., \& Steenkamp, J. (1995). The effects of perceived interdependence on dealer attitudes. Journal of Marketing Research, 32, 348-356.

Lai, K. H., \& Wong, C. W. Y. (2012). Green logistics management and performance: Some empirical evidence from Chinese manufacturing exporters. Omega, 40, 267-282. 
Laosirihongthong, T., Adebanjo, D., \& Tan, K. C. (2013). Green supply chain management practices and performance. Industrial Management \& Data Systems, 113, 10881109.

Large, R., \& Thomsen, C. G. (2011). Drivers of green supply management performance: Evidence from Germany. Journal of Purchasing and Supply Management, 17, $176-184$.

Lazaridesa, H. N. (2011). Food processing technology in a sustainable food supply Chain. Procedia Food Science, 1, 1918-1923.

Lee, S. Y. (2008). Drivers for the participation of small and medium-sized suppliers in green supply chain initiatives. Supply Chain Management: An International Journal, 13, 185-198.

Leonidou, L. (2004). Industrial manufacturer-customer relationships: The discriminating role of the buying situation. Industrial Marketing Management, 33, 731-742.

Linton, J. D., Klassen, R., \& Jayaraman, V. (2007). Sustainable supply chains: An introduction. Journal of Operations Management, 25, 1075-1082.

Luscombe, L. Woolworths' sustainability strategy 2007-2015. Retrieved from http:// www.woolworthslimited.com.au/icms_docs/130514_Doing_the_Right_Thing.Pdf

Mahalik, N. P., \& Nambiar, A. (2010). Trends in food packaging and manufacturing systems and technology. Trends in Food Science; Technology, 21, 117-128.

McAdam, R., Armstrong, G., \& Kelly, B. (1998). Investigation of the relationship between total quality and innovation: A research study involving small organisations. Innovation Management, 1, 139-147.

McWilliams, A., \& Siegel, D. (2001). Corporate social responsibility: A theory of the firm perspective. Academy of Management Review, 26, 117-127.

Mendibil, K., Hernandez, J., Espinach, X., Garriga E., \& Macgregor, S. (2007). How can CSR practices lead to successful innovation in SMES? Response Project, 1-7.

Meier, R. L., Humphreys, M. A., \& Williams, M. R. (1998). The role of purchasing in the agile enterprise. Journal of Supply Chain Management, 34(4), 39-45.

Min, H., \& Galle, W.P. (1997). Green purchasing strategies: Trends and implications. Journal of Supply Chain Management, 33(3), 10-17.

Mohr, J., \& Spekman, R. (1994). Characteristics of partnership success: partnership attributes, communication behaviour and conflict resolution techniques. Strategic Management Journal, 15, 135-152.

Mohr, J. J., Fisher, R. J., \& Nevin, J. R. (1999). Communicating for better channel relationships. Marketing Management, 8(2), 38-45. 
Morgan, R. M., \& Hunt, S. D. (1994).The commitment-trust theory of relationship marketing. Journal of Marketing, 58, 20-38.

Moorman, C., Zaltman, G., \& Deshpande, R. (1992). Relationships between providers and users: The dynamics of trust within and between organisations. Journal of Marketing Research, 29, 314-328.

Monsanto News Room. (2013). Monsanto plays key role in Guatemala greenhouse project. Retrieved from http://news.monsanto.com/news/sustainability/ monsanto-plays-keyrole-guatemala-greenhouse-project

Murray, J. G. (2000). Effects of a green purchasing strategy: The case of Belfast City Council. Supply Chain Management: An International Journal, 5, 37-44.

Murphy, P. R., \& Poist, R. F. (2002). Socially responsible logistics: An exploratory study. Transportation Journal, 41(4), 23-35.

Mutingi, M., \& Mbohwa, C. T. (2012, July). A taxonomic framework for formulating strategies in green supply chain management. Proceedings of the 2012 International Conference on Industrial Engineering and Operations Management (pp. 326-335). Istanbul, Turkey. Retrieved from http://iieom.org/ieom2012/pdfs/87.pdf

Ogbonna, E., \& Wilkinson, B. (1998). Power relations in the UK grocery supply chain: Developments in the 1990s. Journal of Retailing and Consumer Services, 5, 77-86.

Pereira, R. N., \& Vicente, A. A. (2010). Environmental impact of novel thermal and non-thermal technologies in food processing. Food Research International, 43, 1936-1943.

Porter, M. E. (1980). Industry structure and competitive strategy: Keys to profitability. Financial Analysts Journal, 36(4), 30-41.

Porter, M. E., \& Linde, C. V. D. (1995). Green and competitive: Ending the stalemate. Harvard Business Review, 73(5), 120-134.

Prajogo, D. I., \& Sohal, A. S. (2003). The relationship between TQM practices, quality performance, and innovation performance: An empirical examination. International Journal of Quality \& Reliability Management, 20, 901-918.

Preuss, L. (2005). Rhetoric and reality of corporate greening: A view from the supply chain management function. Business Strategy and the Environment, 14, 123-139.

Rao, P. (2002). Greening the supply chain: A new initiative in Southeast Asia. International Journal of Operations \& Production Management, 22, 632-655.

Rao, P., \& Holt, D. (2005). Do green supply chains lead to competitiveness and economic performance? International Journal of Operations \& Production Management, 25, 898-916. 
Ratnayake, R. (1998). Do stringent environmental regulations reduce international competitiveness? Evidence from an inter-industry analysis. International Journal of the Economics of Business, 5, 77-96.

Ross, J. (1993). Total quality management: Text, cases and readings. Delray Beach, FL: St. Lucie Press.

Schaper, M. (2002). Small firms and environmental management: Predictors of green purchasing in western Australian pharmacies. International Small Business Journal, 20, 235251.

Schiele, H. (2006). How to distinguish innovative suppliers? Identifying innovative suppliers as new task for purchasing. Industrial Marketing Management, 35, 925-935.

Shrivastava, P. (1995). Industrial/environmental crises and corporate social responsibility. Journal of Socio-Economics, 24, 211-255.

Smirnova, M., Henneberg, S. C., Ashnai, B., Naudé, P., \& Mouzas, S. (2011). Understanding the role of marketing-purchasing collaboration in industrial markets: The case of Russia. Industrial Marketing Management, 40, 54-64.

Swafford, P. M., Ghosh, S., \& Murthy, N. N. (2006). A framework for assessing value chain agility. International Journal of Operations \& Production Management, 26, 118140.

Tang, Z., Hull, C. E., \& Rothenberg, S. (2012). How corporate social responsibility engagement strategy moderates the CSR-financial performance relationship. Journal of Management Studies, 49, 1274-1303.

Teece, D., \& Pisano, G. (1994). The dynamic capabilities of firms: An introduction. Industrial and Corporate Change, 3, 537-556.

Terpend, R., Tyler, B. B., Krause, D. R., \& Handfield, R. B. (2008). Buyer-supplier relationships: Derived value over two decades. Journal of Supply Chain Management, 44(2), $28-55$.

Testa, F., \& Iraldo, F. (2010). Shadows and lights of GSCM (green supply chain management): Determinants and effects of these practices based on a multinational study. Journal of Cleaner Production, 18, 953-962.

Trienekens, J., Uffelen, R.V., Debaire, J., \& Omta, O. (2008). Assessment of innovation and performance in the fruit chain: The innovation-performance matrix. British Food Journal, 110, 98-127.

Toyota Company. (2010). Environmental leadership in our products. Retrieved from http://www.toyota.eu/sustainability/environmental_performance/sales_

marketing/Pages/products.aspx 
Vachon, S., \& Klassen, R. D. (2006). Extending green practices across the supply chain: The impact of upstream and downstream integration. International Journal of Operations \& Production Management, 26, 795-821.

Vandergeest, P. (2007). Certification and communities: Alternatives for regulating the environmental and social impacts of shrimp farming. World Development, 35, 1152-1171.

Wagner, M. (2007). On the relationship between environmental management, environmental

innovation and patenting: Evidence from German manufacturing firms. Research Policy, 36, 1587-1602.

Walker, H., Sisto, D. L., \& McBain, D. (2008). Drivers and barriers to environmental supply chain management practices: Lessons from the public and private sectors. Journal of Purchasing and Supply Management, 14, 69-85.

Walter, A., Mueller, T. A., \& Helfert, G. (2000). The impact of satisfaction, trust and relationship value on commitment: Theoretical considerations and empirical results. In 16th IMP Conference Proceedings (pp. 1-18). Bath, UK.

Walton, S. V., Handfield, R. B., \& Melnyk, S. A. (1998). The green supply chain: Integrating suppliers into environmental management processes. International Journal of Purchasing \& Materials Management, 34(2), 2-11.

Wang, X., Chan, H. K., Yee, R. W. Y., \& Rainey I. D. (2012). A two-stage fuzzyAHP model for risk assessment of implementing green initiatives in the fashion supply chain. International Journal of Production Economics, 135, 595-606.

Welford, R. (2000). Corporate environmental management III. Towards sustainable development. London: Earthscan.

Westphal, J. D., Gulati, R., \& Shortell, S. M. (1997). Customization or conformity? An institutional and network perspective on the content and consequences of TQM adoption. Administrative Science Quarterly, 42, 366-394.

Weisenfeld, U. (2012). Corporate social responsibility in innovation: Insights from two cases of Syngenta's activities in genetically modified organisms. Creativity and Innovation Management, 21, 199-211.

Wilson, D. T. (1995). An integrated model of buyer-seller relationships. Journal of the Academy of Marketing Science, 23, 335-345.

Wood, D. J. (1991). Corporate social performance revisited. Academy of Management Review, 16, 691-718.

Wu, Z., \& Pagell, M. (2011). Balancing priorities: Decision-making in sustainable supply chain management. Journal of Operations Management, 29, 577-590. 
Xie, Y., \& Breen, L. (2012), Greening community pharmaceutical supply chain in UK: A cross boundary approach. Supply Chain Management, 17, 40-53.

Yamin, S., Mavondo, F., Gunasekaran, A., \& Sarros, J. (1997). A study of competitive strategy, organizational innovation and organizational performance among Australian manufacturing companies. International Journal of Production Economics, 52, $161-172$.

Yen, Y. X., \& Yen, S. Y. (2012). Top-management's role in adopting green purchasing standards in high-tech industrial firms. Journal of Business Research, 65, 951959.

Zhu, Q., \& Sarkis, J. (2004). Relationships between operational practices and performance among early adopters of green supply chain management practices in Chinese manufacturing enterprises. Journal of Operations Management, 22, 265-89.

Zhu, Q., \& Cote, R. P. (2004). Integrating green supply chain management into an embryonic eco-industrial development: A case study of the Guitang Group. Journal of Cleaner Production, 12, 1025-1035.

Zhu, Q., Sarkis, J., \& Geng, Y. (2005). Green supply chain management in China: Pressures, practices and performance. International Journal of Operations and Production Management, 25, 449-468.

Zhu, Q., Sarkis, J., \& Lai, K. H. (2008).Green supply chain management implications for "closing the loop." Transportation Research Part E: Logistics and Transportation Review, 44, 1-18.

Zhu, Q., Sarkis, J., \& Lai, K. H. (2012). Green supply chain management innovation diffusion and its relationship to organizational improvement: An ecological modernization perspective. Journal of Engineering and Technology Management, 29, 168-185. 